九州大学学術情報リポジトリ

Kyushu University Institutional Repository

\title{
Gut Microbiota of Pheretima heteropoda and Allolobophora japonica Fed under the Same Laboratory Conditions
}

\section{NAKAMURA, Kazunori}

College of Engineering, Nihon University | Laboratory of Soils \& Environmental Microbiology, Department of Bioscience and Biotechnology, Graduate School of Bioresource and Bioenvironmental ciences, Kyushu University

SAKAI, Kenji

Laboratory of Soils \& Environmental Microbiology, Department of Bioscience and Biotechnology, Graduate School of Bioresource and Bioenvironmental ciences, Kyushu University

https://doi.org/10.5109/1911179

出版情報: 九州大学大学院農学研究院紀要. 63 (1)，pp.71-74，2018-02-27. Faculty of Agriculture， Kyushu University

バージョン :

権利関係 : 


\title{
Gut Microbiota of Pheretima heteropoda and Allolobophora japonica Fed under the Same Laboratory Conditions
}

\author{
Kazunori NAKAMURA ${ }^{1}$ and Kenji SAKAI* \\ Laboratory of Soils \& Environmental Microbiology, Department of Bioscience and Biotechnology, G \\ raduate School of Bioresource and Bioenvironmental Sciences, \\ Kyushu University, Fukuoka 812-8581, Japan \\ (Received October 31, 2017 and accepted November 20, 2017)
}

\begin{abstract}
Our previous study reported that the gut microbiota of Megascolecidae was distinguishable from that of Lumbricidae. In this study, two earthworms, Pheretima heteropoda (Megascolecidae) and Allolobophora japonica (Lumbricidae), were fed under the same in vitro conditions to investigate the effect of feed on gut microbiota. Their gut microbiota was analyzed by denaturing gradient gel electrophoresis of PCR-amplified 16S rRNA gene fragments. Most of the dominant bands were shared between both earthworm species, but some were specific to one species. These banding patterns corresponded to in situ earthworms, i.e. they were directly analyzed after collection from the field. The predominant bacterium found in $P$. heteropoda gut samples was Bacillus longiquaesitum (AM747042)-related, whereas the predominant bacteria found in A. japonica gut samples were bacterium TG141 (AB308367)-related and Rhizobium sp. BBCT66 (DQ337551)related. These results indicated that the major bacterial species were not influenced by the surrounding environment, including the food source, even though a large portion of the bacterial population was opportunistic.
\end{abstract}

Key words: Allolobophora japonica, earthworm, feeding experiment, gut microbiota, Pheretima heteropoda

\section{INTRODUCTION}

The beneficial effects of earthworms on soil properties are believed to be related to the close relationship that exists between earthworms and the microorganisms found in their gut and the surrounding soil (Brown, 1995). Many studies have been conducted to analyze the gut microbiota of Lumbricidae, which mainly inhabits Europe (ex. Monroy et al., 2008), but few have been reported for Megascolecidae, a major family of earthworms found in Japan (ex. Khambata and Bhat, 1957; Wüst et al., 2009; Nakamura and Sakai, 2011; DepkatJakob et al., 2013). Within the soils of Japan, the majority of earthworms are of the species Pheretima belonging to the Megascolecidae, with only a few reported species belonging to the Lumbricidae (Aoki, 1973; Nakamura, 1968). Previously, we reported that the gut microbiota of the Megascolecidae (Pheretima heteropoda and Pheretima hilgendorfi) was distinguishable from that of the Lumbricidae (Allolobophora japon$i c a$ ), both of which were collected from the same Japanese grassland soil (Nakamura and Sakai, 2011). In addition, our results suggested that the gut microbiota might be influenced by the alimental canal structure rather than by their ecological category; however, we were unable to prove this hypothesis owing to the complex nature of the field samples. Many studies have reported that earthworms have distinct gut microbiota that is predominantly determined by their environment (ex. Furlong et al., 2002). However, one study by Toyota and Kimura (2000) reported that the indigenous

\footnotetext{
College of Engineering, Nihon University, Koriyama 963-8642, Japan

* Corresponding author (E-mail: kensak@agr.kyushu-u.ac.jp)
}

microbial community in the gut of Eisenia fetida (Lumbricidae) was independent of habitat.

In this study, to investigate effect of feed on the gut microbiota of Megascolecidae and Lumbricidae species, the gut contents from two earthworms, $P$. heteropoda (Megascolecidae) and A. japonica (Lumbricidae), fed the same food under in vitro conditions were analyzed.

\section{MATERIALS AND METHODS}

\section{Feeding experiment}

To feed the earthworms, soil and manure were obtained from cattle grazed grassland at Kyushu University, Oita, Japan. The feeding experiment was performed according to Nakamura (1977), with a few modifications, to investigate the effect of soil bacteria. Soil was sieved $(<4 \mathrm{~mm})$ and stored at $4^{\circ} \mathrm{C}$ until further use. Manure was collected from the soil surface, airdried, mechanically fragmented into pieces, and sieved $(<4 \mathrm{~mm})$. Experimental medium (food) for feeding the earthworms comprised soil and manure (1:1 (v/v)).

Adult earthworms (Pheretima (Goto et hatai) and Allolobophora (Michaelsen)) were also collected from cattle grazed grassland at Kyushu University. Species identification was conducted on the basis of characteristic morphological features (Ohfuchi and Yamaguchi, 1965; Nakamura, 1999). Earthworms were washed three times with sterile deionized water, and kept at $16.8^{\circ} \mathrm{C}$ in containers with the experimental medium for 3 days. As reviewed by Brown (1995), earthworms have various gut transit times of up to 20 hours. Three days (72 hours) was found to be sufficient time for food transit in this study.

The feeding experiment was conducted in Petridishes $(9 \mathrm{~cm}$ in diameter), containing the experimental 
medium $(15.4 \mathrm{~g} / \mathrm{dish})$, that were incubated at $16.8^{\circ} \mathrm{C}$ for 3 days (one earthworm/dish). This temperature corresponded to the average soil temperature of the grassland from which the earthworms were collected. The soil moisture content was maintained at around 60\% (dry wt). The feeding experiment was conducted twice under the same conditions. The earthworms used in the first experiment included $11 \mathrm{P}$. heteropoda and $23 \mathrm{~A}$. japon$i c a$. The earthworms used in the second experiment included 22 P. heteropoda and 21 A. japonica.

\section{Analysis of the gut bacterial community structure}

Gut samples were prepared after 3 days of feeding by first washing all earthworms with sterile deionized water three times and then immediately freezing the worms at $-20^{\circ} \mathrm{C}$ until further use. Earthworms were dissected and the gut (gut contents and gut wall) behind segment XX (P. heteropoda) or the clitellum (A. japon$i c a$ ) was equally divided into three parts (fore-gut, midgut and hind-gut).

Total DNA was extracted from the earthworm gut samples and experimental medium using the Fast DNA Spin Kit for soil (Qbiogene Inc., Carlsbad, CA, USA). For further purification, a GENECLEAN ${ }^{\circledR}$ Turbo Kit (Qbiogene Inc.) was used. The DNA concentration was estimated by visual comparison with authentic fragment DNA ( $\lambda /$ HindIII digest) after electrophoresis on an agarose gel. Purified DNA was stored at $-20^{\circ} \mathrm{C}$ until use.

PCR and denaturing gradient gel electrophoresis (DGGE) were performed as described previously (Nakamura and Sakai, 2011). A fragment of the 16S rRNA gene (c. $194 \mathrm{bp}$ ) was PCR amplified from a representative, diluted, purified DNA template using the forward primer, 357f-GC, and the reverse primer, 518r (Muyzer et al., 1993). The PCR reactions were performed in 25 or $50 \mu \mathrm{l}$ (final volume) mixtures containing $20 \mathrm{mM}$ of each primer and Premix Taq [Ex Taq Version] (TaKaRa, Otsu, Japan). Reactions were incubated in a Dice thermal cycler (TaKaRa) using the following protocol: an initial denaturation step for $3 \mathrm{~min}$ at $94^{\circ} \mathrm{C}$; then 30 cycles of $1 \mathrm{~min}$ at $52^{\circ} \mathrm{C}$ (annealing), $1 \mathrm{~min}$ at $72^{\circ} \mathrm{C}$ (elongation), and $1 \mathrm{~min}$ at $94^{\circ} \mathrm{C}$ (denaturation); followed by $1 \mathrm{~min}$ at $52^{\circ} \mathrm{C}$ and $10 \mathrm{~min}$ at $72^{\circ} \mathrm{C}$. DNA amplification was verified using electrophoresis of the PCR products in $1.5 \%$ agarose gels.

DGGE was performed with the DCode ${ }^{\mathrm{TM}}$ Universal Mutation Detection System (Bio-Rad, Hercules, CA, USA), according to the manufacturer's instructions. PCR products (c. $100 \mathrm{ng}$ ) were loaded onto $1 \mathrm{~mm}$ polyacrylamide gels ( $8 \% \mathrm{wt} / \mathrm{vol})$ containing a 30\%-60\% linear gradient concentration of denaturant; 100\% denaturant was defined as $7 \mathrm{M}$ urea and $40 \%$ (vol/vol) formamide. Gel electrophoresis was conducted in $1 \times \mathrm{TAE}$ buffer (40 $\mathrm{mM}$ Tris, $20 \mathrm{mM}$ acetic acid, $1 \mathrm{mM} \mathrm{Na-EDTA;} \mathrm{pH}$ 8.0) at $200 \mathrm{~V}$ and $60^{\circ} \mathrm{C}$ for $5 \mathrm{~h}$. Gels were stained for 30 min with 1:10,000 (vol/vol) SYBR $^{\circledR}$ Green I (TaKaRa) and photographed under ultraviolet (UV) transillumination.

\section{RESULTS AND DISCUSSION}

DGGE analysis of the gut content of earthworms fed under laboratory conditions revealed characteristic bacterial community structures for each earthworm species, with profiles distinguishable from the experimental medium (i.e. food) (Fig. 1). The profiles showed three major groups of bands. The first group was predominant in only one of the earthworm species: band 4 (Bacillus longiquaesitum (AM747042)-related) in P. heteropoda gut samples; and bands 9 and 10 (Bacterium TG141 (AB308367)-related), 12 (Rhizobium sp. BBCT66 (DQ337551)-related) and 16 in A. japonica gut samples. Interestingly, bands 4, 9, 10, 12 and 16, which predominated in one earthworm gut sample only, showed the same migration behavior as previous field samples (Nakamura and Sakai, 2011). The second group was shared by both earthworm species and comprised bands 1, 5 (B. longiquaesitum (AM747042)-related), 6, 7, 11, 13, 14 and 15. Among these, bands 1, 7 and 14 were derived from the experimental medium and their intensity was higher in gut samples. The third group, comprising bands 3 and 8 , predominated in the experimental medium but diminished in intensity during passage through the earthworm intestines. Table 1 shows a comparison of the dominant bands identified in this study with those of a previous study.

DGGE profiles revealed that many dominant bands were present in both earthworm species fed on the same experimental medium under the same laboratory conditions, suggesting that establishment of the earthworm gut microbiota is dependent on the ingested material. These observations were also reported by Knapp et al. (2009) in Lumbricus rubellus. Although many bands

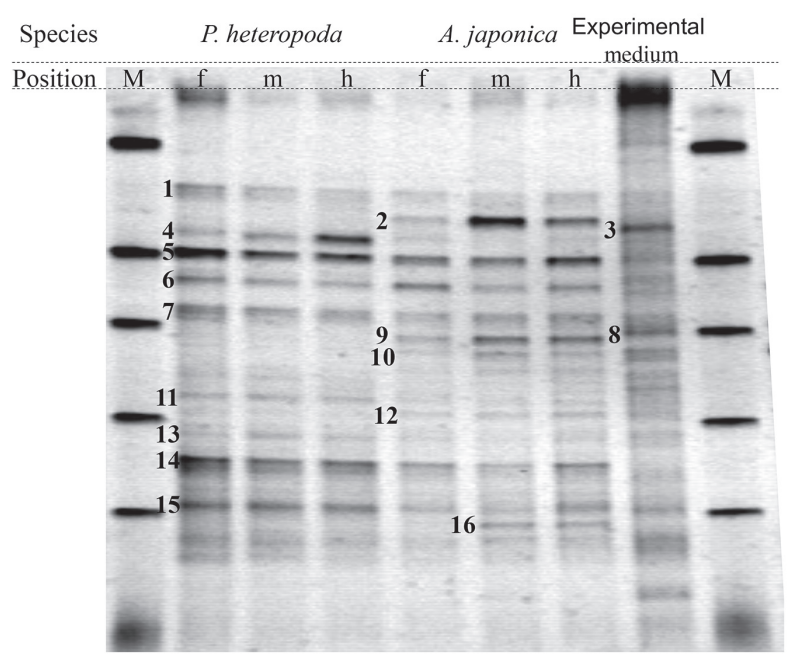

Fig. 1. Typical DGGE profiles for gut samples from $P$. heteropoda and $A$. japonica: f, fore-gut; m, mid-gut; h, hind-gut. Electrophoresis markers (M) were included. Common bands observed in most lanes (1-16) are numbered in the figure. Band 2 indicates the earthworm 18S rRNA gene sequence identified in our previous report (Nakamura and Sakai, 2011). 
Table 1. Dominant DGGE bands detected in this study

\begin{tabular}{|c|c|c|c|c|c|c|c|}
\hline Band & $\begin{array}{l}\text { P. heteropoda } \\
\text { gut }\end{array}$ & $\begin{array}{l}\text { A. japonica } \\
\text { gut }\end{array}$ & $\begin{array}{l}\text { Experimental } \\
\text { medium }\end{array}$ & $\begin{array}{c}\text { Field } \\
\text { samples* }\end{array}$ & $\begin{array}{l}\text { Closest relative in DDBJ database } \\
\text { (accession no.) }\end{array}$ & \% Similarity & $\begin{array}{l}\text { Phylogenetic } \\
\text { group }\end{array}$ \\
\hline 1 & $\bigcirc$ & $\bigcirc$ & $\bigcirc$ & & - & - & - \\
\hline 3 & & & $\bigcirc$ & & - & - & - \\
\hline 4 & $\bigcirc$ & & & $\bigcirc$ & Bacillus longiquaesitum (AM747042) & 99.6 & Firmicutes \\
\hline 5 & $\bigcirc$ & $\bigcirc$ & & $\bigcirc$ & Bacillus longiquaesitum (AM747042) & 99.7 & Firmicutes \\
\hline 6 & $\bigcirc$ & $\bigcirc$ & & $\bigcirc$ & Bacillus longiquaesitum (AM747040) & 97.6 & Firmicutes \\
\hline 7 & $\bigcirc$ & $\bigcirc$ & $\bigcirc$ & & - & - & - \\
\hline 8 & & & 0 & & - & - & - \\
\hline 9 & & $\bigcirc$ & & $\bigcirc$ & Bacterium TG141 (AB308367) & 93.4 & Bacteria \\
\hline 10 & & $\bigcirc$ & & $\bigcirc$ & Bacterium TG141 (AB308367) & 93.4 & Bacteria \\
\hline 11 & O & O & & & - & - & - \\
\hline 12 & & $\bigcirc$ & & $\bigcirc$ & Rhizobium sp. BBCT66 (DQ337551) & 90.9 & Proteobacteria \\
\hline 13 & $\bigcirc$ & $\bigcirc$ & & & - & - & - \\
\hline 14 & 0 & 0 & 0 & & - & - & - \\
\hline 15 & $\bigcirc$ & $\bigcirc$ & & & - & - & - \\
\hline 16 & & $\bigcirc$ & & $\bigcirc$ & - & - & - \\
\hline
\end{tabular}

Note: 1)* Detected in Nakamura and Sakai (2011).

2) Band 2 indicates the earthworm 18S rRNA gene sequence identified in our previous report (Nakamura and Sakai, 2011).

were shared, some bands were specific to each species indicating that species-specific bacteria stably inhabit the earthworm gut, irrespective of their food source. The Proteobacteria that predominated in A. japonica gut samples in this study were consistent with the results of a previous study on field samples (Nakamura and Sakai, 2011), and were also found to dominate the gut contents of Lumbricidae species, such as Lumbricus terrestris (Schönholzer et al., 2002) and L. rubellus (Knapp et al., 2009). There may be factors that activate these bacterial species, for example, the existence of intestinal caecum or the secretion of mucus.

Collectively, this study showed that most of the dominant bacteria were shared between the two earthworm species, $P$. heteropoda and A. japonica. Furthermore, the dominant bacteria derived from the feed material. Our findings suggest that a large portion of the gut bacterial population is opportunistic and depends on the feed material. However, some bacteria were specific to particular earthworm species. These findings showed that the gut bacterial species were not influenced by the surrounding environment, indicating that each earthworm species possess indigenous characteristics that can influence the gut bacteria. Further elucidation of these characteristic features will aid our understanding of the interaction between bacteria and earthworms.

\section{AUTHOR CONTRIBUTIONS}

K. Nakamura designed the study, performed the experiments, analyzed the data and wrote the paper. K. Sakai supervised the work and wrote the paper. All authors assisted in editing of the manuscript and approved the final version.

\section{ACKNOWLEDGEMENTS}

We are grateful to Dr. Takafumi Goto and the staff of Kuju Agricultural Research for their assistance in collecting the earthworms and to Emeritus Prof. Dr. Yoshio Nakamura for his assistance in identifying the earthworms. We thank Dr. Kate Fox from Edanz Group (www.edanzediting.com/ac) for editing a draft of this manuscript.

\section{REFERENCES}

Aoki, J. 1973 Soil Zoology. Hokuryukan, Tokyo (in Japanese) Brown, G. G. 1995 How do earthworms affect microfloral and faunal community diversity? Plant Soil, 170: 209-231

Depkat-Jakob, P. S., G. G. Brown, S. T. Tsai, M. A. Horn and H. L. Drake 2013 Emission of nitrous oxide and dinitrogen by diverse earthworm families from Brazil and resolution of associated denitrifying and nitrate-dissimilating taxa. FEMS Microbiol. Ecol., 83: 375-391

Furlong, M. A., D. R. Singleton, D. C. Coleman and W. B. Whitman 2002 Molecular and culture-based analyses of prokaryotic communities from an agricultural soil and the burrows and casts of the earthworm Lumbricus rubellus. Appl. Environ. Microbiol., 68: 1265-1279

Khambata, S. R. and J. V. Bhat 1957 A contribution to the study of the intestinal microflora of Indian earthworms. Arch. Mikrobiol., 28: 69-80

Knapp, B. A., S. M. Podmirseg, J. Seeber, E. Meyer and H. Insam 2009 Diet-related composition of the gut microbiota of Lumbricus rubellus as revealed by a molecular fingerprinting technique and cloning. Soil Biol. Biochem., 41: 2299-2307

Monroy, F., M. Aira and J. Domínguez 2008 Changes in density of nematodes, protozoa and total coliforms after transit through the gut of four epigeic earthworms (Oligochaeta). Appl. Soil 
Ecol., 39: 127-132

Muyzer, G., E. C. De Waal and A. G. Uitterlinden 1993 Profiling of complex microbial populations by denaturing gradient gel electrophoresis analysis of polymerase chain reaction amplified genes coding for 16S rRNA. Appl. Environ. Microbiol., 59: 695-700

Nakamura, Y. 1968 Studies on the ecology of terrestrial Oligochaeta 1. Seasonal variation in the population density of earthworms in alluvial soil grassland in Sapporo, Hokkaido. Appl. Ent. Zool., 3: 89-95

Nakamura, Y. 1977 Methods of Macro Soil Animals Study. In "Methods of Ecological Study on Soil Animals" ed. by U. Kitazawa, T. Kira, K. Hougetsu, M. Morishita, S. Moji and G. Yamamoto, Kyoritsu Publishing, Tokyo, pp. 8-61 (in Japanese)

Nakamura, Y. 1999 Annelida. In "Pictorial Keys to Soil Animals of Japan" ed. by J. Aoki, Tokai University Publishing, Tokyo, pp. $101-110$ (in Japanese)

Nakamura, K. and K. Sakai 2011 Denaturing gradient gel electro- phoresis analysis of gut bacteria community for the Japanese earthworms. Soil Sci. Plant Nutr., 57: 519-528

Ohfuchi, S. and H. Yamaguchi 1965 OLIGOCHAETA. In "New Illustrated Encyclopedia of the Fauna of Japan", ed. by K. Okada, S. Uchida and T. Uchida, Hokuryu-Kan Publishing Co., Tokyo, pp. 533-563 (in Japanese)

Schönholzer, F., D. Hahn, B. Zarda and J. Zeyer 2002 Automated image analysis and in situ hybridization as tools to study bacterial populations in food resources, gut and cast of Lumbricus terrestris L. J. Microbiol. Methods, 48: 53-68

Toyota, K. and M. Kimura 2000 Microbial community indigenous to the earthworm Eisenia foetida. Biol. Fertil. Soils, 31: 187190

Wüst, P. K., M. A. Horn, G. Henderson, P. H. Jassen, B. H. A. Rehm and H. L. Drake 2009 Gut-associated denitrification and in vivo emission of nitrous oxide by the earthworm families Megascolecidae and Lumbricidae in New Zealand. Appl. Environ. Microbiol., 75: 3430-3436 